\title{
Study of Epidemiology and Human Papilloma Virus Prevalence in Oral Cavity Cancers
}

\author{
Fatimata MBAYE ${ }^{*}$, Henri DIATTA ${ }^{1}$, Mouhamadou Makhtar NDIAYE ${ }^{2}$, Mame Diarra GUEYE $^{1}$, Malick FALL ${ }^{1}$, Bay Karim DIALLO ${ }^{3}$, \\ Silly TOURE ${ }^{2}$ and Mbacké SEMBENE ${ }^{1}$ \\ ${ }^{1}$ Genomics Laboratory, Department of Animal Biology, Faculty of Science and Technology, Cheikh Anta Diop University, Dakar, Senegal \\ ${ }^{2}$ Department of Maxillofacial Surgery and Stomatology, Faculty of Medicine, Pharmacy and Stomatology, Cheikh Anta Diop University, Dakar, Senegal \\ ${ }^{3}$ Department of Otorhinolaryngology, Faculty of Medicine, Pharmacy and Stomatology, Cheikh Anta Diop University, Dakar, Senegal
}

${ }^{\star}$ Corresponding author: Fatimata MBAYE, Genomics Laboratory, Department of Animal Biology, Faculty of Science and Technology, Cheikh Anta Diop University, Dakar, Senegal; Tel: +221773665998; Email: fatimata2.mbaye@ucad.edu.sn

Received: September 14, 2021; Accepted: September 21, 2021; Published: September 25, 2021

\begin{abstract}
Oral cavity cancers (OCC) are the most common malignancies in the subcategory of head and neck cancers, and represent the 6th most common cancer in the world. These cancers have become more frequent in individuals without a history of alcohol-tobacco abuse, which are the major risk factors. Other factors have been suggested, such as viral infections, but especially genetic alterations. This work establishes the epidemiological profile and researches the presence of viral DNA in OCCs. The epidemiology was highlighted with 105 patients using the Epi Info software. HPV DNA was sought in 50 samples of diseased tissue and blood by attempting to amplify its L1 region by PCR. At the epidemiological level, the results show a mean age of 53.2 years, a sex ratio of 0.8 and a low consumption of tobacco (16.2\%) and alcohol (4.8\%). HPV was not detected in any of the samples. Thus, the epidemiological profile of OCCs in Senegal is different from that in other countries, and HPV is not associated with its occurrence.
\end{abstract}

Keywords: Cancer, Oral cavity, HPV, Epidemiology

\section{Introduction}

The epidemiology of cancers of the oral cavity is part of the more general framework of cancers of the upper aerodigestive tract (UADT) [1]. They account for approximately 25 to $30 \%$ of UADT cancers [2]. In general, they appear from the sixth decade of life [3] with alcohol and tobacco being identified as the main risk factors. They are ranked as the $6^{\text {th }}$ most common cancer worldwide, and $3^{\text {rd }}$ in developing countries [4]. Globally, they had 354,864 new cases in 2018, or $2 \%$ of all cancers, and approximately 177,384 cases of deaths, or $1.9 \%$ of cancer deaths [5]. Men account for $69.4 \%$ of cases, with a higher cumulative risk of dying before age 75 . Age-standardized incidence rates are lower in West Africa, with little difference between men and women at 1.2 and 1.1 cases per 100,000 persons/year, respectively $[5,6]$. The five most affected countries are India (77,003 cases), the United States (26,064 cases), China (21,413 cases), Pakistan (12,761 cases), and Bangladesh (10,550 cases) [7]. Reports have shown that the global incidence is higher in more developed regions, but mortality is higher in less developed regions, which reflects social inequality [8].

According to GLOBOCAN [9], it is the $16^{\text {th }}$ most common cancer in Senegal, with 130 new cases during the last 5 years and 111 deaths. The average age is about 52 years and the female sex predominates, with the majority being non-alcoholic-tobacco users [10,11]. In Africa in general and in Senegal in particular, data on cancers of the oral cavity are scarce and besides that the epidemiology differs from other countries.
Based on epidemiologic and clinicopathologic evidence, it has been proposed that Human Papillomavirus (HPV) infection is linked to the development of oral cancer [12]. HPV is one of the most common sexually transmitted infections and belongs to a large family of viruses, the papovaviridae. They are small (about $55 \mathrm{~nm}$ in diameter) and epitheliotropic. Their genome is composed of 7,200 to 8,000 base pairs with molecular weights of $5.2 \times 10^{6}$ daltons. They have a double-stranded circular DNA with a capsule of 72 capsomers of icosahedral structures, without a lipoprotein envelope [13]. Numerous papillomaviruses are known, with over 150 types; however, not all genotypes are considered carcinogenic [14]. Based on their potential oncogenic activity, HPV subtypes have been divided into high-risk (HPV-HR) and low-risk (HPV-LR) viruses. HPV-HR are associated with cancer development and are called viral "oncogenes" [15]. The prevalence of HPV in normal oral mucosa (latent infection) and its relationship to oral cancer have generated conflicting opinions. Most of the published studies have included several head and neck subsites, which have prevented specific analysis of HPV involvement in oral carcinogenesis [16]. In addition, the frequency of HPV infection in oral cavity cancer shows a lot of variation between studies around the world [17]. To support the implication of HPV in oral tumors, few studies have been conducted to determine the frequency of HPV DNA exclusively in squamous cell carcinoma of the oral cavity, particularly in Senegal. Hence, this study aims to update the epidemiological profile of oral cavity cancers and to detect the presence of HPV in them. 


\section{Methodology}

This study was approved by the Research Ethics Committee of Cheikh Anta Diop University (Reference: Protocol 0272/2018/ CER/UCAD). One hundred and five (105) patients diagnosed with OCCs between March 2017 and October 2020, at the Department of Stomatology and Maxillofacial Surgery of the Hospital Center University Aristide Le Dantec in Dakar were the subject of this study. Demographic, clinico-pathological, and etiological data were collected from the patients' clinical records and then entered with Microsoft Excel 2016 spreadsheet for statistical analyzes, thereby allowing the description of the epidemiological profile of OCC in Senegal. Epi Info software version 7.2.4.0 enabled these analyses to be carried out by providing, among other things, the number of patients, the frequency, and the $95 \%$ confidence interval for each parameter studied. For statistical tests, a $\mathrm{p}$ value $<0.05$ is considered significant.

DNA extraction was performed from blood and tissue using the Zymo research kit and the Purelink viral RNA/DNA kit according to the manufacturer's conditions. In order to test for the presence of viral DNA in the OCCs, the L1 gene was amplified using the primer pair (MY09/11). PCR was performed using $25 \mu \mathrm{l}$ of master mix, 1 $\mu \mathrm{l}$ of forward primer, $1 \mu \mathrm{l}$ of reverse primer, $1 \mu \mathrm{l}$ of $\mathrm{MgCl}_{2}, 20 \mu \mathrm{l}$ of ultrapure water and $2 \mu \mathrm{l}$ of DNA. The following conditions were used: $94^{\circ} \mathrm{C}$ for $5 \mathrm{~min}$; 35 cycles $\left(94^{\circ} \mathrm{C}\right.$ for $30 \mathrm{~s}, 55^{\circ} \mathrm{C}$ for $30 \mathrm{~s}, 72^{\circ} \mathrm{C}$ for 1 $\mathrm{min}$ ); $72^{\circ} \mathrm{C}$ for $15 \mathrm{~min}$. A positive control (PC) for cervical cancer was used.

\section{Results}

\section{Characteristics of the Population}

The clinical parameters of the one hundred and five (105) patients enrolled in this study are listed in Table 1. More than half (55.4\%) come from the different regions of Senegal. Age at diagnosis ranged from 22 to 90 years, with $38.1 \%$ of patients aged between 50 and 64 years old. There was a slight predominance of women, with a sex ratio of 0.8 , and they were older than men (55.7 years vs. 49.9 years) with a non-significant p-value of 0.12 . Histologically,
93.3\% of cases are squamous cell carcinomas, and are generally well differentiated (64.8\% of cases). Different structures of the mouth are affected: the gum (30.5\% of cases), the tongue (17.1\%) and the inner face of the cheek (15.2\%) are the most affected. Among the patients whose tumor size was reported, the majority ( 23 cases) were larger than $4 \mathrm{~cm}$ in size. The presence of lymphadenopathy (s) was noted in $21.9 \%$ of patients, and $48.6 \%$ were at an advanced stage (stage III or IV). The rate of alcohol and tobacco use was low, with only $16.2 \%$ of smokers and $4.8 \%$ of alcohol users. Note that $21.9 \%$ of cases have poor oral hygiene.

Table 2 shows the distribution of age groups in relation to gender. For all age groups, the incidence is higher in women except those under 35 years of age.

\section{Amplification Reactions of the HPV L1 Region}

The result of this PCR for 10 cancerous tissue and one positif control is shown in figure 1 . The latter shows the absence of viral DNA for our samples, except for the positive control which shows a band, of about $450 \mathrm{bp}$. The result is the same for all samples (tissue and blood).

\section{Discussion}

One of the first activities of this study was to collect tumor samples as well as clinical data from patients with OCC at the Department of Stomatology and Maxillofacial Surgery of the Hospital Center University Aristide Le Dantec. Of the 105 cases, 59 (56.2\%) were women as opposed to $46(43.8 \%)$ men. This shows that in Senegal, there is a slight predominance of women in the incidence of OCC, with a sex ratio of 0.8 . This sex ratio is identical to that found in Senegal by Dieng et al. [11], and not far from the result of Millogo et al. [18] in Burkina with a sex ratio of 0.85. In this study, the hypothesis is supported according to which the aesthetic concern would lead women of our societies to consult more often than men as soon as a significant anomaly is noticed in the oro-maxillo-facial sphere. However, oral cancer is considered worldwide as a male pathology and especially in the most affected countries like India [7]. Indeed, in India, a study by Singh et al. [19] identified $84.8 \%$ of men as opposed to $15.2 \%$ of women.

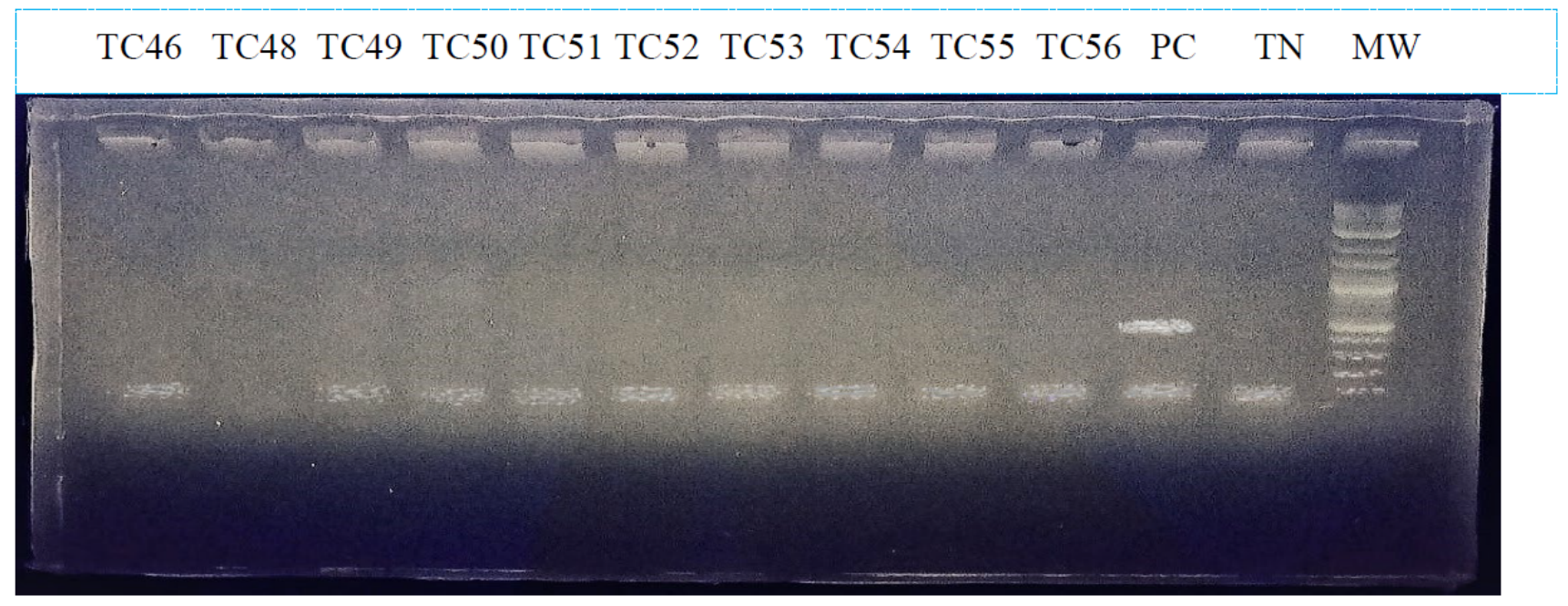

Figure 1: Electrophoretic migration profile of PCR products from the L1 region. MW: molecular weight; TC = Cancerous tissue PC: positive control; TN: negative control 
Fatimata MBAYE (2021) Study of Epidemiology and Human Papilloma Virus Prevalence in Oral Cavity Cancers

Table 1: Epidemiological and clinical characteristics of patients.

\begin{tabular}{|c|c|c|c|}
\hline Characteristics & Minimum & Maximum & Average \\
\hline \multicolumn{4}{|l|}{ Age (year) } \\
\hline Overall age & 22 & 90 & 53.2 \\
\hline Men & 22 & 78 & 49.9 \\
\hline \multirow[t]{2}{*}{ Women } & 25 & 90 & 55.7 \\
\hline & Number & Frequency (\%) & CI $(95 \%)$ \\
\hline \multicolumn{4}{|l|}{ Gender } \\
\hline Male & 46 & 43.8 & $34.1-53.8$ \\
\hline Female & 59 & 56.2 & $46.2-65.9$ \\
\hline Sex ratio & 0.8 & & \\
\hline \multicolumn{4}{|l|}{ Age groups } \\
\hline Under 35 years & 19 & 18.1 & $11.3-26.8$ \\
\hline 35 years - 49 years & 19 & 18.1 & $11.3-26.8$ \\
\hline 50 years - 64 years & 40 & 38.1 & $28.8-48.1$ \\
\hline 65 years and older & 27 & 25.7 & $17.7-35.2$ \\
\hline \multicolumn{4}{|l|}{ Origin } \\
\hline Dakar & 41 & 39 & 29.7-49.1 \\
\hline Other regions & 55 & 52.4 & $42.4-62.2$ \\
\hline Neighboring countries & 9 & 8.6 & $4-15.6$ \\
\hline \multicolumn{4}{|l|}{ Histopathology } \\
\hline Squamous cell carcinoma & 98 & 93.3 & $86.7-97.3$ \\
\hline Adenoid carcinoma & 1 & 1 & $0-5.2$ \\
\hline Verrucous carcinoma & 1 & 1 & $0-5.2$ \\
\hline Sarcoma & 4 & 3.8 & $1-9.5$ \\
\hline Lymphoma & 1 & 1 & $0-5.2$ \\
\hline \multicolumn{4}{|l|}{ Differentiation } \\
\hline Good & 68 & 64.8 & $54.8-73.8$ \\
\hline Average & 15 & 14.3 & $8.2-22.5$ \\
\hline Weak & 8 & 7.6 & $3.3-14.5$ \\
\hline NA & 14 & 13.3 & 7.5-21.4 \\
\hline \multicolumn{4}{|l|}{ Tumor site } \\
\hline Gum & 32 & 30.5 & $21.9-40.2$ \\
\hline Tongue & 18 & 17.1 & $10.5-25.7$ \\
\hline Cheek & 16 & 15.2 & $9-23.6$ \\
\hline Lip & 8 & 7.6 & $3.3-14.5$ \\
\hline Palate & 6 & 5.7 & $2.1-12$ \\
\hline Floor & 2 & 1.9 & $0.2-6.7$ \\
\hline Facial mass & 9 & 8.6 & 4-15.6 \\
\hline Mixed & 14 & 13.3 & $7.5-21.4$ \\
\hline \multicolumn{4}{|l|}{ Tumor size $(\mathrm{cm})$} \\
\hline $\mathrm{T} \leq 2$ & 3 & 2.9 & $0.6-8.1$ \\
\hline $2<\mathrm{T} \leq 4$ & 18 & 17.1 & $10.5-25.7$ \\
\hline $\mathrm{T}>4$ & 23 & 21.9 & $14.4-31$ \\
\hline Large extension & 18 & 17.1 & $10.5-25.7$ \\
\hline NA & 43 & 41 & $31.5-51$ \\
\hline \multicolumn{4}{|l|}{ Lymphadenopathy } \\
\hline Positive & 23 & 21.9 & $14.4-31$ \\
\hline Negative & 82 & 78.1 & $69-85.6$ \\
\hline \multicolumn{4}{|l|}{ Stage } \\
\hline Early (stage I + stage II) & 13 & 12.4 & $6.8-20.2$ \\
\hline Advanced (stage III + stage IV) & 51 & 48.6 & $38.7-58.5$ \\
\hline $\mathrm{NA}$ & 41 & 39 & $29.7-49.1$ \\
\hline \multicolumn{4}{|l|}{ Common risk factors } \\
\hline Tobacco & 17 & 16.2 & $9.7-24.7$ \\
\hline Alcohol & 5 & 4.8 & $1.6-10.8$ \\
\hline No Alcohol-smoking & 66 & 62.8 & $52.9-72.1$ \\
\hline $\mathrm{NA}$ & 17 & 16.2 & $9.7-24.7$ \\
\hline \multicolumn{4}{|l|}{ Oral hygiene } \\
\hline Poor & 23 & 21.9 & $14.4-31$ \\
\hline Good/NA & 82 & 78.1 & $69-85.6$ \\
\hline TOTAL & 105 & 100 & \\
\hline
\end{tabular}


Table 2: Distribution of the different age groups in relation to gender.

\begin{tabular}{|c|c|c|c|c|c|}
\hline \multirow[b]{2}{*}{ Age groups } & \multicolumn{2}{|c|}{ Men } & \multicolumn{2}{|c|}{ Women } & \multirow[b]{2}{*}{ Total } \\
\hline & Number & Frequency (\%) & Number & Frequency (\%) & \\
\hline Under 35 years & 13 & 68.4 & 6 & 31.6 & 19 \\
\hline $35-49$ years & 8 & 42.1 & 11 & 57.9 & 19 \\
\hline $50-64$ years & 14 & 35 & 26 & 65 & 40 \\
\hline 65 years and older & 11 & 40.8 & 16 & 59.2 & 27 \\
\hline
\end{tabular}

P-value $=0.11$

Cancer is a disease whose risk increases with age. In Europe and America, the average age of patients with OCC is estimated to be around 60 years old [3]. In Africa, the average age range is from 47.8 years in Côte d'Ivoire to 49.15 years in Burkina [18]. In our study, the modal class 50 - 64 years represents $38.1 \%$ of the cases (40 patients), with a mean age of 53.2 years for the entire study population. This result is close to those found by Touré et al. [10] and Dieng et al. [11] with 52.6 and 52.9 years of mean age, respectively. This age difference with developed countries could be explained by the difference in standard of living and therefore easier access to medical care, disfavoring for example poor oral hygiene for these populations $[2,18]$. Indeed, poor oral hygiene is thought to play a direct role in the occurrence of OCCs [20] and it may play a non-negligible role in Senegal [21]. It was often poor in the study by Touré et al. [10], and for the study of Millogo et al. [18], all patients experienced poor oral hygiene. In our case, these represent $21.9 \%$ of the study population, but with missing data.

Despite the fact that older people are more exposed, our results show that young people are also not spared from the disease, especially among men. In fact, in our results, 38 patients were not yet in their fifties and 19 of them were under 35 years of age, $68.42 \%$ of whom were men. Touré et al. [10] had observed in their cohort that $38 \%$ of patients were under 50 years of age. In many countries of the world, there has been an alarming increase in the incidence of oral cancer, especially among young men [3]. This could be explained by earlier exposure to common risk factors such as tobacco use [7] as is the case in India or Pakistan. In these regions, the average age of patients is between 41 and 50 years and one-third of the population aged 15 years uses tobacco in any form [22]. However, the consumption of these substances (tobacco and alcohol) is not common among patients with OCC in Senegal $[10,11]$. Our results confirm this with only 17 smokers ( $16.2 \%$ of cases), and 5 alcoholics (4.8\%). The low alcohol consumption is explained by the fact that $95 \%$ of the population is Muslim [21].

The fact that $93.3 \%$ of the cases in our study were squamous cell carcinomas is not surprising, since it is well known that they account for more than $90 \%$ of all oral cancers [23]. Most studies have confirmed the predominance of squamous cell carcinomas, but with different frequencies. They were the predominant histological type for: Singh et al. [19] for all cases (100\%), Dieng et al. [11] with $98 \%$ of cases, and $55.9 \%$ for Millogo et al. [18]. The latter support the hypothesis that the predominance of squamous epithelial tissue in the mucosa is the cause of this high frequency of squamous cell carcinomas.

The tongue is one of the most common sites in OCCs with $40 \%$ of cases [8] especially in Western countries due to excessive smoking and alcohol consumption [22]. In 2005, according to Touré et al. [10], the mandible (24.8\%), tongue (21.9\%) and maxilla (15.2\%) represented the majority sites. The gum (30.5\% of cases), tongue (17.1\%) and inner face of the cheek (15.2\%) are the most affected sites in our study. The fact that the maxillary and mandibular gingiva are grouped together may have caused this high rate for the gingiva. This distribution of tumor sites could be explained by poor dental hygiene: either non-healing after dental extraction, creating an open wound in the gum area; or decayed teeth, traumatizing the cheek or tongue, especially for the latter.

More than half of OCCs were diagnosed at stage III or IV [20]. This was the case in Senegal based on previous studies with an average of $86 \%$ of cases diagnosed at advanced stages $[10,11]$. For $48.6 \%$ of the cases in our study, the disease was at an advanced stage (stage III or IV), with the presence of lymphadenopathy in 23 cases (21.9\%). However, a lot of data are missing to make an estimate of the stage of the disease in our study population. The diagnosis at an advanced stage shows an irregularity or a late consultation of our population at the level of oral care structures, which can be explained by a weakness at the financial level or by the ignorance for example of the early signs of the disease. Other authors such as Millogo et al. [18] point to the omnipresence of traditional medicine as perhaps the first resort in our societies

This epidemiological study has certain limitations, such as the large number of unspecified data for a few parameters, or the failure to take into account other parameters such as occupation. The existence of a register or database of oral cancers, which compiles data from all hospital services receiving patients with this pathology, would allow us to know a little more about this disease and its incidence in Senegal.

Searching for HPV DNA was also one of the objectives of the study. It was done by gene amplification of its $\mathrm{L} 1$ region on 50 extracts of cancerous tissue and 50 extracts of blood, and none revealed the presence of this virus. This suggests that there is no significant association between OCCs and HPV infection. Ndiaye et al. [21] found only 3.4\% HPV-positive cases in a study conducted in Senegal on head and neck cancers (HNC). This study, in addition to our own, shows that the prevalence of HPV in HNCs in Senegal is low. This is more or less the same observation that has been made in some African countries. For example, HPV was found in $6.3 \%$ of HNC cases in a study in South Africa; [24] 0.74\% in Central Africa for Kofi et al. [25]; and like our case, it could not be detected in studies in Mozambique [26] and Nigeria [27]. These results are different from what has been reported in other parts of the world. In a systematic review by Kreimer et al. [28] compiling data from 60 studies, the overall HPV positivity was 25.9\%; and North American countries were more representative 
than Europe or Asia. Ndiaye et al. [29] reported a positivity of 31.5\% when compiling 148 studies. Ndiaye et al. [21] argue that there are ethnic disparities regarding the prevalence of the virus in these cancers, with less of it being found to affect the black race. Indeed, studies in the US have shown this to be the case [30,31]. For example Settle et al. [30] found 34\% positivity in whites as opposed to $4 \%$ in blacks. This racial difference would be explained by risky sexual practices, especially oral sex, which is believed to be more prevalent among whites; but also by genetic differences between the two groups, impacting host immunity or viral integration [27]. It also appears that smoking, besides being an independent risk factor in developed countries, makes infections more likely to persist, thus increasing the risk of developing HPV-related diseases [32].

Furthermore, it is recognized that the highest prevalences of HPV infection in HNCs are found in the oropharynx (45.8\%) including the tonsils (53.9\%), compared to $24.2 \%$ for the oral cavity [29]. Thus, the oral cavity is not the preferred site for HPV in HNCs.

\section{Conclusion}

As a result of the heterogeneous etiology and lack of definite prognosis of oral cavity cancers, this study aimed to contribute to a better understanding of the epidemiological and molecular profile of patients with OCC in Senegal. An epidemiological profile different from that of Western or Asian countries was found. Indeed, it is that of a relatively young individual, often of a female gender, nonalcoholicsmoker. Added to this is the absence of HPV in patients with OCC in Senegal. Thus, the risk factors are not yet clearly identified, and this opens the way to the search for other factors such as those related to the environment, lifestyle or diet, but especially genetic events.

\section{References}

1. Barthélémy I, Sannajust JP, Revol P, Mondié JM (2005) Cancers of the oral cavity. Preamble, epidemiology, clinical study. EMC-Oral Maxillofac Surg 1.

2. Bissa H, Darre T, Pegbessou PE, Amana P, et al. (2014) Histo-epidemiological profile of cancers of the oral cavity, about 66 cases observed in Togo. Rev Col OdontoStomatol Afr Chir Maxillo-fac 21: 5-9.

3. Adeola DS, Obiadazie AC (2006) Oro-facial carcinoma in Kaduna. Niger J Surg Res 8: 144-147.

4. Patil NN, Wadhwan V, Chaudhary M, Nayyar AS (2016) KAI-1 and P53 Expression in oral squamous cell carcinomas: Markers of significance in future diagnostics and possibly therapeutics. J Oral Maxillofac Pathol 20: 384-389.

5. Bray F, Ferlay J, Soerjomataram I, Siegel RL, Torre LA, et al. (2018) Global Cancer Statistics 2018: GLOBOCAN Estimates of Incidence and Mortality Worldwide for 36 Cancers in 185 Countries. CA: Cancer J Clin 68: 394-424. [crossref]

6. Ferlay J, Colombet M, Soerjomataram I, Mathers C, Parkin DM, et al. (2019) Estimating the global cancer incidence and mortality in 2018: GLOBOCAN sources and methods. Int J Cancer 144: 1941-1953. [crossref]

7. Salehiniya H, Raei M (2020) Oral cavity and lip cancer in the world: An epidemiological review. Biomed Res Ther 7: 3898-3905.

8. Rivera C (2015) Essentials of oral cancer. Int J Clin Exp Pathol 8: 11884-11894. [crossref]

9. Global Cancer Observatory (GLOBOCAN)/2018 data. Cancer Today. International Agency for Research on Cancer/OMS.

10. Toure S, Sonko L, Diallo BK, Diop R, et al. (2005) Epidemiological profile of oral cavity cancers in Senegal. J Stomatol Maxillofac Surg 106: 68-71.

11. Dieng MM, Dem A, Gaye PM, Diouf D, Toure S, et al. (2012) Cancers of the oral cavity: about 145 cases at the Joliot-Curie Institute in Dakar. Cancer/Radiother 16: 547.
12. Betiol J, Villa LL, Sichero L (2013) Impact of HPV infection on the development of head and neck cancer Brazilian. J Med Biol Res 46: 217-226.

13. Alvarenga GC, Sá EMM, Passos MRL, Pinheiro VMS (2000) Human papillomavirus and cervical carcinogenesis. J Bras Doenças Sex Transm 12: 28-38.

14. Wagner S, Sharma SJ, Wuerdemann N, Knuth J, Reder H, et al. (2017) Human papillomavirus-related head and neck cancer. Oncol Res Treat 40: 334-340. [crossref]

15. Lafaurie GI, Perdomo SJ, Buenahora MR, Amaya S (2018) Human papilloma virus: An etiological and prognostic factor for oral cancer? J Investig Clin Dent 9: 11.

16. Paolini F, Rizzo C, Sperduti I, Pichi B, Mafera B, et al. (2013) Both mucosal and cutaneous papillomaviruses are in the oral cavity but only alpha genus seems to be associated with cancer. J Clin Virol 56: 72-76. [crossref]

17. Abreu PMD, Gregório AC, Pedro Leite Azevedo PL, Valle IBd, Oleiviera KGD, et al. (2018) Frequency of HPV in oral cavity squamous cell carcinoma. BMC cancer 18 : 324. [crossref]

18. Millogo M, Bambara TA, Ouédraogo RWL, Konsem T, et al. (2019) Oro-maxillofacial cancers at the Yalgado Ouédraogo University Hospital Center in Ouagadougou. Rev Col Odonto-Stomatol Afr Chir Maxillo-fac 26: 42-47.

19. Singh RD, Patel KR, Patel PS (2016) P53 mutation spectrum and its role in prognosis of oral cancer patients: a study from Gujarat, west India. Mutat Res 783: 15-26. [crossref]

20. Bambara AT, Millogo M, Konsem T, Bambara HA, et al. (2015) Cancers of the oral cavity: predominantly female disease in Ouagadougou. Med Buccale Chir Buccale 21: 61-66.

21. Ndiaye C, Alemany L, Diop Y, Ndiaye N, Dieme MJ, et al. (2013) The role of human papillomavirus in head and neck cancer in Senegal. Infect Agents Cance 8: 14.

22. Anwar N, Pervez S, Chundriger Q, Awan S, Moatter T, et al. (2020) Oral cancer: Clinicopathological features and associated risk factors in a high-risk population presenting to a major tertiary care center in Pakistan. PLoS One 15: 0236359.

23. Bagan J, Sarrion G, Jimenez Y (2010) Oral Cancer: Clinical Features. Oral Oncol 46: $414-417$.

24. Sekee TR, Burt FJ, Goedhals D, Goedhals J, Munsamy Y, et al. (2018) Human papillomavirus in head and neck squamous cell carcinomas in a South African cohort. Papillomavirus Res 6: 58-62. [crossref]

25. Kofi B, Mossoro-Kpinde CD, Mboumba Bouassa RSM, Péré H, Robin L, et al. (2019) Infrequent detection of human papillomavirus infection in head and neck cancers in the Central African Republic: A retrospective study. Infect Agents Cancer 14: 9. [crossref]

26. Blumberg J, Monjane L, Prasad M, Carrilho C, Judson BL, et al. (2015) Investigation of the presence of HPV related oropharyngeal and oral tongue squamous cell carcinoma in Mozambique. Cancer Epidemiol 39: 1000-1005. [crossref]

27. Oga EA, Schumaker LM, Alabi BS, Obaseki D, Umana A, et al. (2016) Paucity of HPV-related head and neck cancers (HNC) in Nigeria. PLoS One 11: e0152828. [crossref]

28. Kreimer AR, Clifford GM, Boyle P, Franceschi S (2005) Human papillomavirus types in head and neck squamous cell carcinomas worldwide: a systematic review. Cancer Epidemiol Biomarkers Prev 14: 467-475. [crossref]

29. Ndiaye C, Mena M, Alemany L, Arbyn M, Castellsague S, et al. (2014) HPV DNA, E6/ E7 mRNA, and P16 ${ }^{\text {INK4a }}$ detection in head and neck cancers: a systematic review and meta-analysis. Lancet Oncol 15: 1319-1331. [crossref]

30. Settle K, Posner MR, Schumaker LM, Tan M, Suntharalingam M, et al. (2009) Racial survival disparity in head and neck cancer results from low prevalence of human papillomavirus infection in black oropharyngeal cancer patients. Cancer Prev Res. (Phila) 2: 776-781. [crossref]

31. Weinberger PM, Merkley MA, Khichi SS, Lee JL, Psyrri A, et al. (2010) Human papillomavirus-active head and neck cancer and ethnic health disparities. Laryngoscope 120: 1531-1537. [crossref]

32. Hübbers CU, Akgül B (2015) HPV and Cancer of the Oral Cavity. Virulence 6: 244248. [crossref]

\section{Citation:}

MBAYE F, DIATTA H, NDIAYE MM, GUEYE MD, FALL M, et al. (2021) Study of Epidemiology and Human Papilloma Virus Prevalence in Oral Cavity Cancers. Mol Genet Res Open Volume 4(2): 1-5. 